\title{
Problems and Countermeasures of Linyi Hotel Real Estate Development and Management
}

\author{
Zhong-Xiu LIU \\ Department of Real estate, School of Architectures, Linyi University, Linyi, Shandong Province, \\ China \\ liuzhongxiu@lyu.edu.cn
}

Keywords: Problems, Countermeasures, Development, Management, Hotel Real Estate, Linyi.

\begin{abstract}
In recent years, the development of real estate projects gets into the new stage of integration. The joint of the related industries and real estate is showing from different angles. This paper describes the conception of hotel real estate. As non- professionals, there are many problems in the process of hotel production and operation. Some countermeasures are put forward in the paper. It is great significance for hotel real estate decision-makers, developers and investors.
\end{abstract}

\section{The Conception OF Hotel Real Estate}

In recent years, the development of real estate projects gets into the new stage of integration. The joint of the related industries and real estate is showing from different angles. Hotel real estate becomes the biggest bright spot of the real estate industry. The emergences of some of the hotel real estate projects have not only brought new opportunities for the real estate market, but also provide a new model of product development and management for developers.[1]

Hotel is a kind of organization whose buildings is its certificate, which obtains the economic benefits through the sale of rooms, food and beverage, as well as full-service facilities to provide services to the guests. Real estate is land, buildings, and the inalienable part fixing on the land, buildings and with a variety of interests. Therefore, the hotel real estate is the fusion of hotel and real estate. Hotel real estate refers to the residential project with 70 years of property rights, which can sell as the average residential, but its construction planning and supporting all performed in accordance with the standard of the hotel, unified operation by the professional hotel management company to ensure the investment income.[2]

\section{Problems in Linyi Hotel Real Estate Development and Management}

\section{Luxury Hotels Sprawl}

In general, the number of investment hotel from high-end to low-end should be rendered pyramid structure, in Linyi the structure of investment hotel is opposite, showed extremely unreasonable structure of the status quo. The real estate property investors are undoubtedly the most powerful promoters of this phenomenon. From the view of the investors, their concern is the rate of return on investment, and the return on investment will generally be short-term and long-term survey. Short-term return on investment is operating profit minus the cost of the owners. It is not optimistic in Linyi hotel industry. The long-term return on investment is short-term profits, land and asset appreciation. Thus, long-term investment returns is the main considerations for real estate developers to enter the hotel industry. Real estate investors spotted short-term profits and long-term assets appreciation features of high-star hotel, so they built real estate hotel everywhere in the concept of "high standard, high range".[3]

\section{Lack of Knowledge on the Hotel Industry Led to Blind Investment}

On the base of the main operating project, the current real estate hotel investors are divided into two categories: one is real estate investors who have a strong strength. Their main business is real estate investment. They have practical experience in the development of commercial real estate, but also have great economic and business strength. The other is the other industries investors who engaged in other industries instead of the real estate. They completed the primitive accumulation of capital in the other 
industries. Due to various reasons, they are optimistic about the hotel industry and invest in real estate hotel. With strong capital and experience on construction of hotel, professional real estate investors are generally favorable in hotel real estate investment. At the same time, some small and medium-sized real estate investors have to build a hotel because the local government requires them to build the hotel with the project. Special, third-tier cities are higher passion for the introduction of high-end hotels. These cities hope the substantial developer to construct high-end hotels to enhance the city image. Favorable conditions to attract foreign investment, the local government may give some land to developers to build residential. Some developers build hotels to enhance the land housing prices. Therefore, the "package" policy of the government, some investors are passive blindly into the real estate hotel industry in the temptation of commercial and residential real estate. ${ }^{[4]}$

The other industries investors who engaged in other industries instead of the real estate is active blindly invest hotel. Investors who are successful in other industries will consider before they decide to invest in real estate hotel: In addition to their own business, what industry can they do? When they cannot find appropriate business, most investors decided to invest real estate hotel. They simply think that to enter real estate hotel is lower barriers. As long as they fully fund, and hire specialized Hotel Management Company after the completion, the hotel can easily profit. Disregard of the current tourism situation, ignorance of the hotel construction and operation, overestimated revenue of high-end hotels result in a non-professional real estate investor's blind investment in the real estate hotel.[5]

\section{Lack of a Proper Understanding of the Hotel Management Company's Operating Model}

At present, most of the "real estate + hotel" mode operate like this. After real estate investors built hotel, they hire a professional hotel management company to manage it. Driven by goal of high-star hotel, investors generally tend to choose well-known international brand Management Company. Unimpressive understanding of the management company or hotel brand will result in an increasing difficulty of opening and operation, as well as the inevitable runaway budget and additional inputs. ${ }^{[6]}$

In general, the well-known international hotel management companies have been decades or even centuries of accumulation; have developed strict brand standards for the management of the hotel. The standards of its management of the hotel gives the full range of detailed rules, and even hotel sanitary appliance brand requirements, the texture of the carpet, etc. are clearly defined. Once the hardware requirements cannot reach the management company, the opening time will be postponed indefinitely. Only the owner has been converted to the opening of the management company standard, the hotel can operate formally. By reason of Investors, the cognitive deficits of the hotel, misunderstand the hotel's internal structure and operation of the specification, unsharpness detail in hotel management company selecting manage hotel, on the occasion of the hotel construction, decoration, supporting cannot achieve the requirements of the company, which will lead to the postponed opening time. At the same time, in order to open, the developers have to continue to invest to improve the hardware facilities of the hotel to achieve the standard of the opening of the management company, eventually lead to the over-investment of the developer.[7]

\section{Countermeasures on Linyi Hotel Real Estate Development Issues}

\section{Tourism Administration Departments Strengthen Macro-control, Strictly Examine and Approve}

In the face of disordered development of the real estate hotel, tourism administration department should further strengthen macro-control, strictly examine and approve to ensure a reasonable number of hotels structure in charge of the development of the tourist hotels. Tourism industry authorities and planning departments should establish and improve the coordination of oversight mechanisms.

As you can see from the current investment boom in real estate hotel in Linyi, hotel investment has gone into the misunderstanding. The most direct expression is that the structure and the number of hotels is extremely unreasonable. High-star hotels and low-star hotels are not showing a pyramid structure but inverted pyramid structure in the number. Especially high-star hotels gradually rise every year. Investors are in pursuit of high-star and luxury, which does not meet with the needs of the market. Although the market mechanism will make those unreasonable hotel automatically exit the hotel industry market, but 
in the end affected the healthy development of Linyi hotel industry to some extent. Therefore, based on the need to promote healthy and coordinated development of the hotel industry in Linyi, the tourism administration departments should intensify supervision responsibility in terms of real estate hotel entrance approval. Industry associations should also give investors professional guidance in terms of industry trends, development status, and market supply and demand situation.[8]

\section{Real Estate Investors Understand the Hotel Industry Status to Avoid Blind Investment}

Real estate investors decided to invest in real estate hotel, the feasibility study should be strengthened, repeated verification of the reliability of the inputs and the rate of return, based on the current tourism market, regional economic conditions to determine whether or not invest real estate hotel, or what kind of real estate hotel invest, rather than blind investment in high-star hotel.

Linyi high-star hotel market supply growth is much higher than demand growth for high-end tourism now. Linyi high-star hotels take international tourists as the main target group. The impact of the financial crisis on inbound tourism as the main profit point of high-star hotel is also evident. If investors don't take into account the international economic potential as well as the domestic tourism industry trends, it is unwise to enter the hotel industry.[9]

\section{Investors and Hotel Management Companies Should Establish a Healthy Cooperation Way}

Although a growing number of real estate investors have been introduced different brands of international hotel management companies, but local developers and international hotel management companies just took a difficult step. Many developers have little knowledge of hotel operations management, ambiguous mode of operation of the hotel management company, hinder the operation and development of the hotel. Currently, Linyi hotel owners and management companies cooperation way is, after the completion of the hotel, the owners hire a professional hotel management company to operate and manage the hotel. To some extent, this unhealthy ways of cooperation ignored the early stage of cooperation of hotel with the hotel management company. Naturally the way cannot avoid the events like hardware cannot reach the requirements of the management company, the delayed opening time for rectification, additional investment. Therefore, healthy and reasonable cooperation way is that hotel management company is best early involved in the design of the hotel. The management companies understand the problems of the hotel in the design and construction and timely solve them to good future operating management.

\section{Hotel Owners Shouldl Establish Their Own Professional Hotel Management Team}

Hotel owners and hotel management companies exists convergence blind spot, which result many difficulties in the early cooperation. Between hotel owners and management companies need to integrate agents to achieve effective communication as more as possible to reduce unnecessary losses. Therefore, hotel owners should have a certain number of hotel management professionals; they can be stationed in the hotel on behalf of the hotel owners to work with hotel Management Company. They commonly referred to as "owners' representative". The responsibility of owners' representative is not only supervision after opening, but also of include the hotel management contract negotiations, hotel pre-preparation, hotel financial reporting and budget review, daily operation report and external public relations. Have their own professional hotel management team, investors will get professional guidance in various stages of development in the hotel, which can avoid misunderstand to a certain extent.[10]

\section{Conclusions}

This paper describes the conception of hotel real estate, combined with the specific circumstances of Linyi City, introduce the hotel real estate development model and management model, as well as the existing problems and countermeasures in the development of the hotel real estate. With the hotel market demand continues to expand, the impact of the national macro-policy, more and more real estate developer invest hotel real estate. As non- professionals, there are many problems in the process of hotel construction and operation. This paper summary the problems and make recommendations, but there is not comprehensive. Further found problems inthe hotel real estate development, it is great significance for hotel real estate decision-makers, developers and investors. 


\section{Reference}

[1]Li Ye; Chen Liwen; Cao Xiaoli; Hotel Real Estate Projects Risk Assessment Study Based on Life Cycle Theory, Jiangsu Theory, 2011 (2): 32-34.

[2]Lv Xiaojing, First Exploration on Hotel Real Estate, Modern Business 2012 (6): 53-54.

[3]Shu Yang, Timeshare: Real Estate Development Innovation, China Real Estate, 2003 (7): 63-65.

[4]Han Bing, Study on Development and Problems of the Property Hotel, Knowledge Economy, 2010 (21): 114 .

[5 Li Yibin, Property Hotel Investment Strategy, Finance Analysis, 2008 (5): 76-77.

[6]Yu Feifei, Zuo Zhongming, Research on Domestic Property Hotel, Journal of Chizhou College, 2009, 23 (3): 96-99.

[7]Liu Zhiliang, Study on the Development of Shenzhen Service Apartment, Commercial Research, 2005 (17): 166-167.

[8]Mu Zhenzhen, Research on Real Estate Property Development, Commercial Age, 2009 (36): 105-106.

[9]Yin Zhen, Talk about the Hotel Real Estate Development and Operation Model, Master's Degree Thesis of Chongqing University, 2006.

[10]Gao Jinrui, Analysis on Development of Property Hotel in our Country, Modern Commercial, 2010 (29): 140-141. 